\title{
花弁の展開にともなう細胞肥大と花の形
}

\author{
市村一雄 \\ 農研機構花き研究所 305-8519 つくば市藤本 2-1
}

\section{Cell Expansion during Flower Opening Associated with Flower Shape}

\author{
Kazuo Ichimura
}

\author{
National Institute of Floricultural Science, Fujimoto 2-1, Tsukuba, Ibaraki 305-8519
}

\section{はじめに}

花きに扔いて，花弁を展開させることは非常に重要であ る. 特に, バラでは観賞の主体が花弁の展開する過程であ ることから，花弁の展開を何らかの方法で制御することが 望まれている.

花弁は展開しながら成長する. これに関してガイラル ディアの舌状花では，花弁を構成する細胞の分裂は比較的 早い段階で停止することが明らかにされている（Koning， 1984). また, カーネーションでは, 花弁中の DNA 含量の 増加は花弁ががく片から現れた時期にプラトーに達するこ とが報告されている（Kenisら，1985）。これらの結果から， 展開にともなら花弁の成長は主として細胞の肥大成長に よって起こるとされている.

細胞が肥大するためには細胞内へ水が流入することと細 胞壁がゆるむことが必要である. 細胞への水の流入は, 糖 質, 無機イオンあるいは有機酸などの物質が細胞内に蓄積 し浸透圧が上昇することによって起こると考えられてい る. 切り花への糖質の処理は花弁の展開を促進することか ら, このよらな浸透圧調節物質のらち, 花弁の展開には糖 質が最も重要と考えられている.

著者らの研究グループは, 花弁細胞の肥大には, 浸透圧 調節物質として液胞に蓄積する糖質が重要であることを明 らかにした．さらに，花の形にも糖質の蓄積が関与してい る可能性も示唆される. 今回はこれらの研究結果を中心に 解説する.

\section{細胞肥大と浸透圧調節物質}

浸透圧調節物質として機能している主な物質には糖質, 無機イオンおよび有機酸があげられる.

葉や茥では無機イオンが主要な浸透圧調節物質として機 能している. 無機イオンの中ではカリウムが浸透圧維持に 最も重要である. カリウム以外にカルシウム, マグネシウ

2007 年 10 月 25 日 受付. 2007 年 12 月 13 日 受理.

E-mail: ichimu@affrc.go.jp
ム，硝酸などの無機イオンが浸透圧維持に重要であること が明らかにされている（Cram, 1976; Leigh・Tomos, 1993）.

トマトやリンゴなどの果実やサトウキビの茥のように糖 質が蓄積する組織では, 糖質が主要な浸透圧調節物質となっ ている（Damon ら，1988; Welbaum・Meinzer, 1990; Yamaki・ Ino, 1992）。このような組織では糖質は液胞に蓄積する．蓄 積する糖質は主としてグルコース, フルクトース拈よびスク ロースである. 後述するように花弁でも糖質が浸透圧調節物 質として重要であることが明らかにされつつある.

他にリンゴ酸をはじめとする有機酸も浸透圧調節物質と して機能していることが知られている (Cram, 1976; Welbaum・ Meinzer, 1990).

\section{花弁に蓄積する糖質}

植物に存在する低分子の糖質にはさまざまな種類があ る. そのらち，グルコース，フルクトース拉よ゙スクロー スはどのような器官に拈いてもほとんど普遍的に存在し, 呼吸基質および浸透圧調節物質として重要な役割を果たし ている.

花きではバラ，キクおよびカーネーションなどをはじめ として，花弁の展開にともない蓄積する糖質はグルコース とフルクトースであるものが多い（第1図）（Ichimura ら， 1998, 1999b, 2000b). 一方, トルコギキョウあるいはスイー トピーのようにフルクトースがあまり蓄積しないものでは グルコースとスクロースが蓄積する（Ichimura ら，1999a; Shimizu・ Ichimura, 2005).

このような普遍的な代謝糖以外に，植物種により特異的 な糖質が蓄積する場合がある。リンドウではゲンチビオー スとゲンチオトリオースが構成糖質であることが知られて いる. このらち，ゲンチオビオースはリンドウの最も主要 な構成糖質となっている（市村ら，2005）。また，バラでは キシロースとメチルグルコシドが構成糖質となっている (Ichimura ら, 1997).

また，一部の花きではポリオール（糖アルコール）が主 要な構成糖質となっており，デルフィニウムではマンニ トール，フロックスでは2-C-メチルエリトリトールが花弁 
中の主要な糖質であり，これらの濃度は花弁の展開にとも ない上昇する（Enomoto ら，2004; Ichimura ら，2000a). 従っ て，これらの花きではこのような糖質が浸透圧調節物質と して重要であることが示唆される，その他，シクリトール （イノシトール）が主要な構成糖質となっている花きもあ る. ミオイノシトールは植物に普遍的に分布する. カーネー ションではメトキシ化したイノシトールであるピニトール が主要な構成糖質である（Ichimura ら，1998）。また，キク ではL-イノシトールとシリトール (Ichimura 5, 2000b)，ト ルコギキョウとスイートピーではボルネシトールが主要な 構成糖質である（市村ら，1997; Ichimura ら，1999a）。しか し, これらシクリトール類の濃度は比較的高くても, 開花 にともなら濃度の上昇は認められず，花弁の展開に打いて シクリトール類の重要性を示す結果は報告されていない.

\section{花弁の展開における貯蔵炭水化物の役割}

植物に打いて，デンプンは重要な貯蔵炭水化物である. バラ ‘ソニア’ 切り花を用いた実験では，花弁が展開する 過程でデンプン含量は減少し, 単糖含量が増加することが 報告されている（Evans・Reid, 1988）。そのため, 花弁に貯 蔵されたデンプンが花弁展開にともなら糖質濃度の上昇に 寄与していると考えられてきた。 しかし，著者らがバラの 樹上で開花した花を用いて解析したところ, 花弁の展開に ともないデンプン含量は減少するが, その減少は増加した 単糖含量に比較するとごくわずかであった． ステージ 2

\section{A}
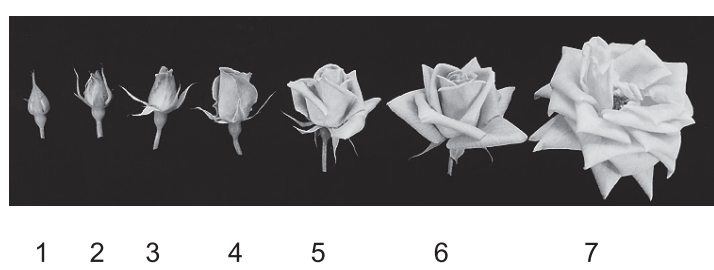

B

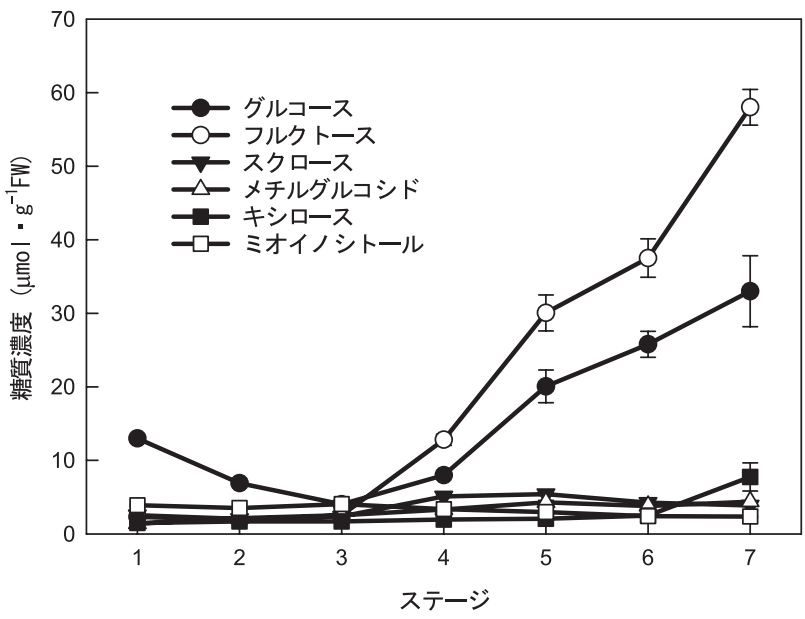

第1図 バラ ‘ソニア’ の花弁展開にともなら花の形態 (A) と糖質濃度の変化 (B) 值は平均値 $\pm \mathrm{SE} （ \mathrm{n}=3)$
（第 1 図）にほぼ相当する段階で収穫したバラ切り花を材 料とした Evans・Reid（1988）の報告では，花弁の展開に ともない増加した糖質含量は，樹上花に打けるそれに比較 するとごく少量である．従って，樹上で開花した花のよう に花弁が十分に展開するためには，花弁中に貯蔵されてい たデンプンだけでは不十分であり，葉からの光合成産物の 供給が不可欠であると考光られる. バラ以外にも, カーネー ション，キンギョソウ，トルコギキョウなど，多くの花き で，花弁の展開にともない糖質濃度は上昇するが，この上 昇はデンプンの分解では説明できないことが見出された (乘越ら，未発表)。従って，花弁展開に打けるデンプンの 貯蔵炭水化物しての役割は限られたものと又なされる.

一日花であるへメロカリスではフルクタンが貯蔵炭水化 物として重要であることが明らかにされて拈り，花弁が展 開する過程でフルクタンが分解し，その最終的な分解産物 であるグルコースとフルクトースが花弁に蓄積し，浸透圧 の上昇に寄与していることが報告されている（Bieleski, 1993). また, カンパニュラでもフルクタンが重要であるこ とが示唆されている（Vergauwen ら，2000）。

\section{細胞内の糖質分布を解析する手法}

花弁に輸送された糖質は液胞に蓄積し，浸透圧調節物質 として細胞肥大に寄与していると考えられている。そのた め, 花弁展開機構の解析には液胞中の糖質の定量が必要で ある．液胞中の糖質濃度を測定する方法には 4 種類があげ られる。具体的には，直接液胞を単離する方法，マイクロ マニピュレーターにより液胞液を採取する方法，コンパー トメントアナリシス法ならびに疎水性溶媒密度勾配遠心分 画法である.

液胞中の物質を定量する最も直接的な方法は，組織から 液胞を単離し，その物質濃度を測定することである。液胞 は組織からプロトプラストを単離した後,さらに溶媒の $\mathrm{pH}$ を上昇させるともに浸透圧を低下させることにより単離す ることが可能である (Wagner, 1979; Yamaki, 1984). しかし， 単離にはある程度の時間を要するため，操作する過程で内 容物質が変動する可能性が示唆されている。

マイクロマニュピレーターによる液胞液の採取はアサガ オの花弁で報告されている（Yoshida ら，1995）。この方法 は操作に熟練を要することに加え, 多量の液胞液を採取す ることが困難であるため，物質の定量が容易ではないとい ら欠点がある.

コンパートメントアナリシス法は物質の細胞内分布を 比較的簡単に解析する方法として幅広く用いられている （McKenzie ら，2004; Yamaki・Ino, 1992）。この方法は組織 を適当な緩衝液中に浸漬し，時間の経過にともない溶媒に 溶出する糖質の濃度変動を調べる方法である。この方法で は, 最初にアポプラスト, 次いで細胞質, 最後に液胞から 細胞内成分が溶出することが前提とされている. 溶出曲線 の変曲点から，アポプラスト，細胞質および液胞に含まれ 
る糖質の分布を計算する。

疎水性溶媒密度勾配遠心分画法は操作中の物質の変化を 抑制し，より正確に代謝物質の分布を解析する方法として 開発された（Gerhardt・Heldt, 1984）。疎水性溶媒密度勾配 遠心分画法では，凍結乾燥した組織の粉末を四塩化炭素と ヘプタンから作成された密度勾配液に重層し，遠心分離を 行なう（第 2 図）．密度の大きい液胞は下側に，密度の小さ いクロロプラストは上側に分布する。 ただし，この方法に よりそれぞれの画分をコンタミネーションなく分離するこ とはできないそそこで，マーカー酵素と目的とする物質の 分離パターンから，計算により物質の細胞内分布を算出す る. この方法により，ホウレンソウ，才オムギ，キンギョ ソウなどの葉あるいはジャガイモ塊茎おける糖質, 光合成 代謝産物あるいはアミノ酸などの細胞内分布が報告されて いる (Farré ら, 2001; Moore ら, 1997; Winter ら, 1993, 1994).

これら 4 種類の方法のらち，液胞を直接単離する方法と マイクロマニュピレーターを使用する方法ではアポプラス ト中の物質は別途測定しなければならない。コンパートメ ントアナリシス法では液胞だけでなく，細胞質とアポプラ

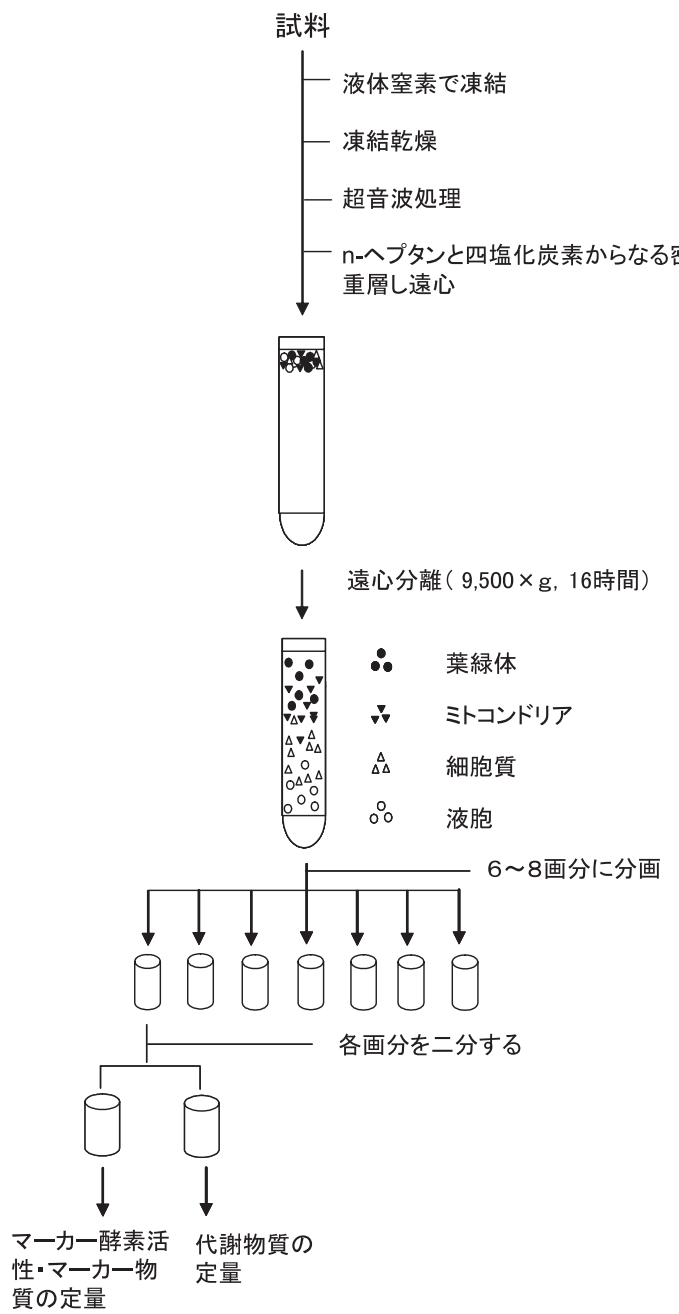

第 2 図 疎水性溶媒密度勾配遠心分画法の概要
ストの物質濃度の定量が可能である。しかし，それぞれの コンパートメントからの相互のコンタミネーションを避け ることは原理的に不可能である。疎水性溶媒密度勾配遠心 分画法では主として液胞，細胞質およびクロロプラストに おける物質の分布が解析されてきた。果実など糖質を多量 に蓄積する器官ではアポプラストにも多量の糖質を蓄積す ることが知られている。 ところが，疎水性溶媒密度勾配遠 心分画法ではアポプラストに含まれる物質の分布の報告は 1 報のみであり，乙かもこの報告では液胞と細胞質の物質 分布は調べられていない（MacDougall ら，1995).

\section{細胞内の糖質分布を解析する手法の開発}

バラ花弁を材料にして，疎水性溶媒密度勾配遠心分画法 により糖質の細胞内分布の解析が可能であるかどうかを検 討した。 アポプラストは膜で覆われていないため, アポプ ラスト画分が疎水性溶媒中でどのような挙動を示すのか不 明である。アポプラスト画分以外には分布していない可溶 性ペクチンをアポプラストのマーカー物質として選抜し,

A

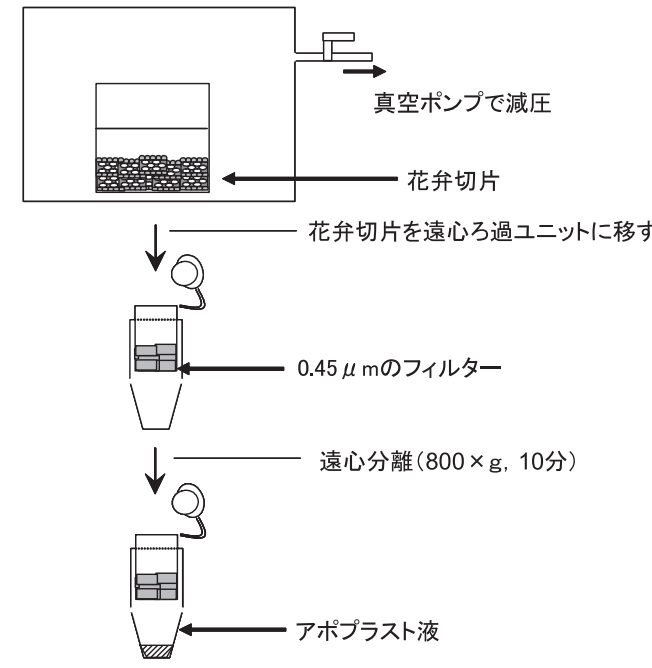

B

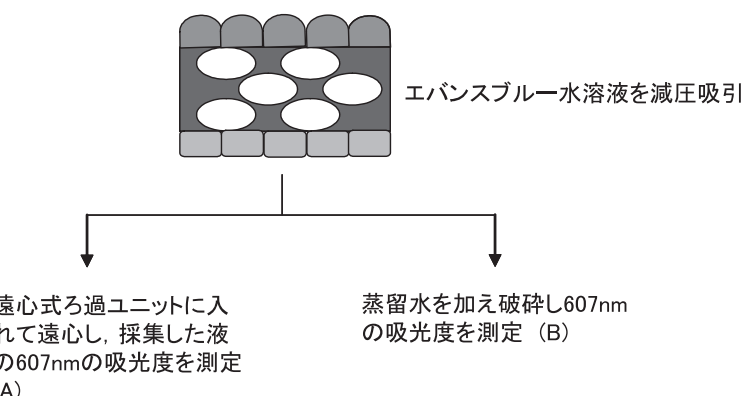

(A)

(A)/(B) $\times 100$ をアポプラスト液の回収率とする

第 3 図 Infiltration- 遠心分離法の概要（A）と Infiltration- 遠心 分離法に打けるアポプラストに含まれる物質の回収率 の測定（B） 
アポプラスト，細胞質拉よび液胞のマーカー酵素あるいは マーカー物質がどのような分布を示すかを調查したとこ ろ, バラ花弁ではアポプラストのマーカーである可溶性ぺ クチンと液胞のマーカーである $\alpha$-マンノシダーゼの分離が 不十分であった. 従って, 解析結果飞誤りを生じることが 危惧され，この方法の久で物質の細胞内分布を解析するこ とは困難と判断した.

アポプラスト中の物質を分離する方法として, 組織をそ のまま低速で遠心し，分離された液をアポプラスト溶液と する方法（Tsurusaki ら，1997）が最も簡便である. しかし， この方法では適用できる組織が限られている。そのため, 組織のエアスペースを溶液で満たしてから低速で遠心する ことにより採取する Infiltration- 遠心分離法が一般的である (Cosgrove $\cdot$ Cleland, 1983; Speer $・$ Kaiser, 1991). しかし, Infiltration-遠心分離法ではアポプラスト液を完全に回收するこ とは不可能である。 そこで, 細胞内には浸透できない色素 であるエバンスブルーを用いて回収率を算出する方法を開 発し，アポプラスト中の糖質含量を定量する方法を確立し た（第 3 図）(乘越ら，2003）.

次いで，疎水性溶媒密度勾配遠心分画法と回収率算出を 可能とした Infiltration- 遠心分離法を組久合わせることに より，液胞，細胞質およびアポプラストに拈ける糖質の分 布を解析する方法を確立した，具体的な手順としては，ま ずInfiltration- 遠心分離法によりアポプラスト中の糖質含量 を測定する，次いで，疎水性溶媒密度勾配遠心分画法によ り, 液胞, 細胞質扣よびアポプラストに拈ける糖質の分布 を解析する。 アポプラストに含まれる物質は理論的には疎 水性溶媒密度勾配遠心分画法により分画されることになる ため, 蹯水性溶媒密度勾配遠心後, それぞれの画分からア ポプラストの糖質含量を減じる，さらに，液胞と細胞質の 分布をRiens ら（1991）の方法に基づき算出する。 これに より, 液胞, 細胞質执よびアポプラストにお咑る糖質の分 布を解析することが可能であると考兄られる.

\section{バラの花弁の展開にともなう 糖質細胞内分布とその濃度の変動}

バラ 'ソニア’ の花弁を用い, 疎水性溶媒密度勾配遠心 分画法と回收率算出を可能とした Infiltration- 遠心分離法を 組又合わせ，花弁の展開にともなら液胞，細胞質およびア ポプラストにおける糖質の分布を解析したところ，花弁の 展開にともない液胞に糖質が多量に蓄積することが判明し た.ささらに, 各画分の糖質濃度を算出するため, 透過型電 子顕微鏡写真により花弁細胞の液胞, 細胞質, 細胞壁拉よ びエアスペースに相当する部分の面積比を測定し，それに 基づき液胞, 細胞質拈よびアポプラストの糖質濃度を算出 した。 アポプラストはエアスペースを含むが，エアスペー スには液体は存在しないため，ここでは細胞壁の面積に基 づき算出した值をアポプラストの濃度とした。 その結果, 花弁の展開にともない, どの画分においても糖質濃度が著

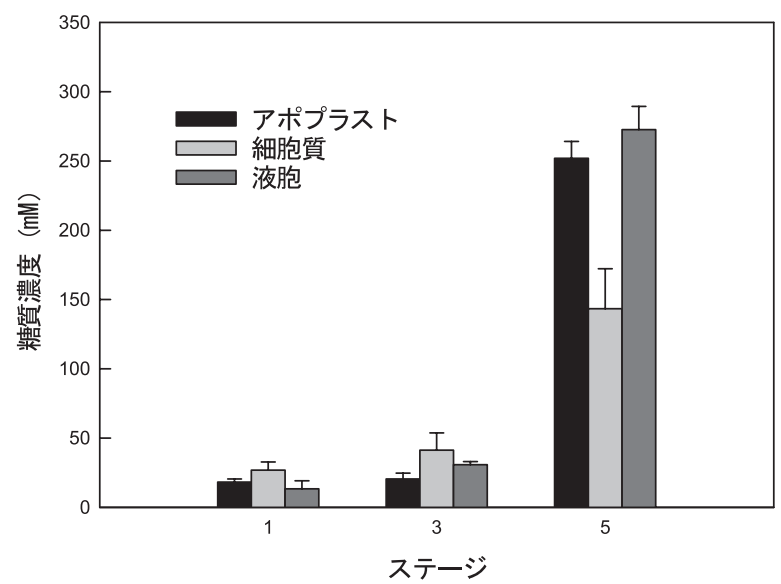

第 4 図 バラ ‘ソニア’ の花弁展開にともなら液胞, 細胞質お よびアポプラストに抢ける糖質濃度の変化 值は平均值 $\pm \mathrm{SE} （ \mathrm{n}=3)$

しく上昇することが判明した（第 4 図）.

液胞が肥大するためには，液胞中の浸透圧はアポプラス トよりも高いことが必要である。シンプラストの大部分は 液胞であり, 細胞質も含む。 そこで, バラの花弁展開にと もならシンプラストとアポプラストの浸透圧を測定したと

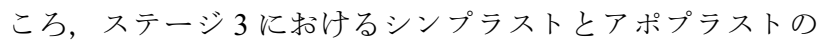
浸透圧はそれ杂れ $793 \mathrm{kPa}$ 就よび $169 \mathrm{kPa}$ であり, ステージ 5 ではそれぞれ $1,324 \mathrm{kPa}$ 打よび $961 \mathrm{kPa}$ に上昇した。特に ステージ 3 ではシンプラストの浸透圧のほらがアポプラス トのそれよりもはるかに高かったことから，両者の浸透圧 差により水の流入が可能であると考兄られた.

糖質と無機イオンがどの程度浸透圧維持に貢献している かを明らかにするため，シンプラストとアポプラストに拉 いてそれぞれに由来する浸透圧を算出した。 シンプラスト とアポプラストに扔ける糖質由来の浸透圧は，ステージ 3 ではそれぞれ $92 \mathrm{kPa}$ 打よび $57 \mathrm{kPa}$ であり, ステージ 5 では それぞれ $737 \mathrm{kPa}$ 打よび $699 \mathrm{kPa}$ であった. 一方，シンプラ ストとアポプラストに抢ける無機イオン由来の浸透圧は, ステージ 3 ではそれ矢れ $265 \mathrm{kPa}$ 捄よび $64 \mathrm{kPa}$ であり, ス

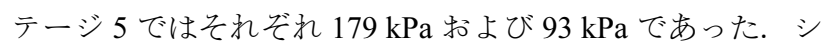
ンプラストに扎いて，浸透圧の上昇は糖質に由来する浸透 圧の上昇とほぼ一致したことから，花弁展開にともなら浸 透圧の上昇は液胞への糖質の蓄積によることが示唆され た。またシンプラストとアポプラストとの浸透圧差には 無機イオンの関与が大きいことも示された.

花弁の展開にともない, グルコースとフルクトース濃度 が著しく上昇したことを考光合わせると，花弁細胞の肥大 機構を以下のように説明することが可能である.すなわち, 無機イオン等，糖質以外の物質によりシンプラストとアポ プラストとの間に浸透圧差を生じさせる。 それとともに糖 質を連続的にアポプラストさらには液胞に輸送することに より浸透圧を上昇させる．浸透圧を高めながら細胞内外の 浸透圧差を維持することにより，水を多量に液胞に流入さ 
せ，これにより細胞を肥大させることが可能になると考え られる(乘越ら，2005）。

\section{バラ花形の品種間差と細胞の形態}

花弁組織は主として向軸側表皮細胞，背軸側表皮細胞お よび柔細胞から構成されている。 バラ ‘ソニア’では，花 弁が展開する前のステージでは表皮細胞だけでなく, 柔細 胞も密に存在する. 花弁の展開にともない, それぞれの細 胞が肥大するが, 特に向軸側表皮細胞では横方向の肥大成 長が著しく, その横径は約 3 倍に増加する. また, 柔細胞 は次第に不定形となり，それにともないエアスペースの体 積が著しく増加する（第 5 図）.
バラは長い育種の歴史があり，様々な花形の品種が存在 する。“ソニア’ は弁先が剣状となる剣弁高芯形の品種であ る. 弁先が剣状になるといらことは花弁の展開にともない 向軸側表皮細胞の成長が背軸側表皮細胞の成長よりも著し いことを意味している，一方，近年人気を集めているオ一 ルドローズあるいはイングリッシュローズタイプの品種は 弁先が丸状となる丸弁型が多い.

樹上で開花した ‘ソニア’ は典型的な剣弁を示すが，適 期とされるステージで収穫した切り花を水に生けると丸弁 状となる，一方，生け水に抗菌剂を含むスクロース等の糖 質を加えることにより，樹上と同様に剣弁状となる，一方， ‘ソニア’ と同様に剣弁高芯形の ‘デリーラ’ では，水に生
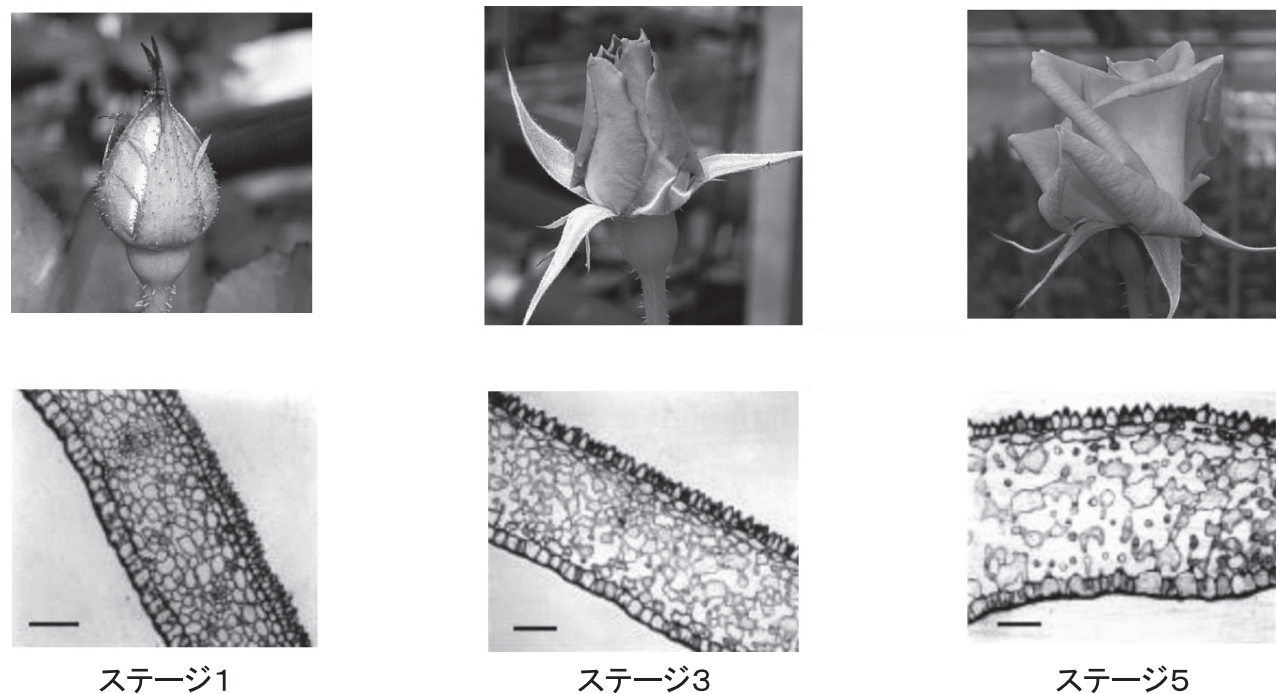

ステージ5

第 5 図 バラ ‘ソニア’ の花弁展開にともなら細胞形態の変化

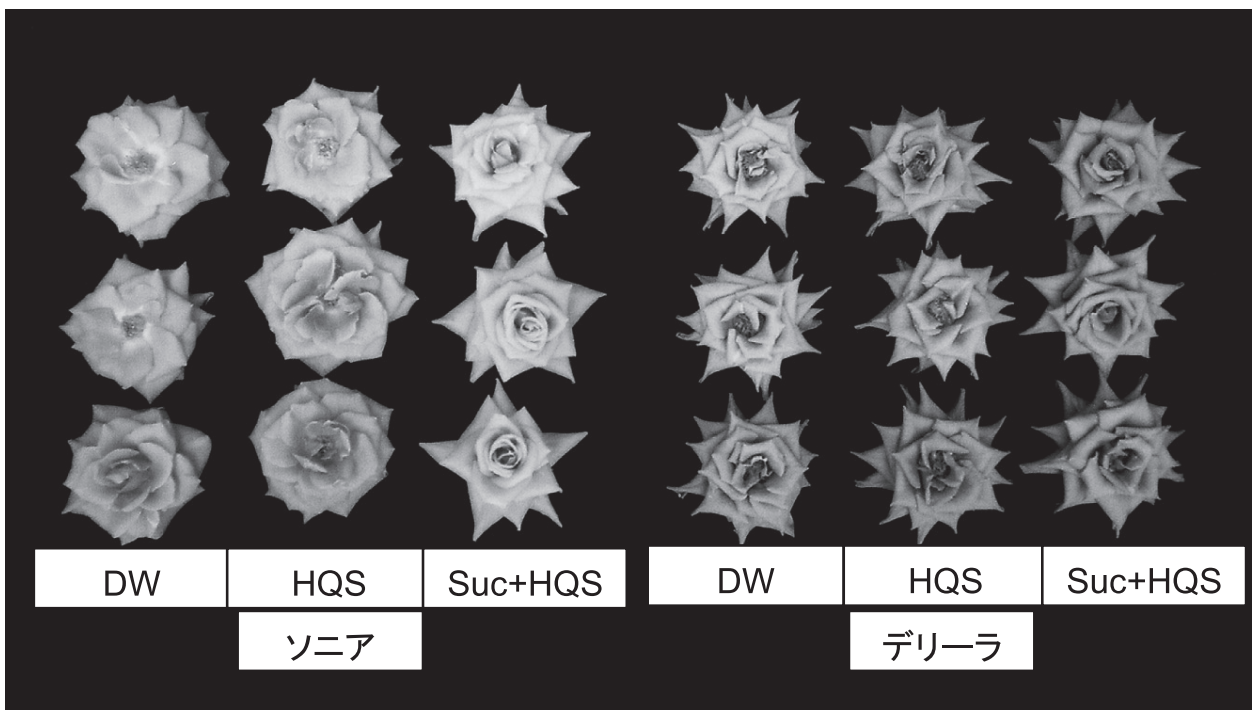

第 6 図 バラ‘ソニア’と ‘デリーラ’の花の形態に及ぼす HQS (抗菌剤) およびスクロースと HQS を組合わせた連続処理の影響 Suc + HQS : スクロース + HQS HQS とスクロースの濃度はそれぞれ $200 \mathrm{mg} ・ \mathrm{~L}^{-1} ， 2 \%$ とした。 
けただけで剣弁状となる（第 6 図）。“デリーラ’は収穫時 点での糖質濃度が ‘ソニア’よりも著しく高いことから， 剣弁化にともなら花弁の成長は糖質に依存している可能性 が高いと考えられる（Ichimura ら，2005）.

また，丸弁形の品種である ‘プロフィータ’ と剣弁形の 品種である ‘ソニア’に打ける表皮細胞の肥大パターンを 観察したところ, ‘ソニア’ は‘プロフィータ’に比較する と向軸側表皮細胞の肥大程度が著しかった. 従って，この よらな細胞肥大のパターンがバラ花形の品種間差に関与し ていることが示唆される. ‘ソニア’の花弁では肥大成長が 盛んなステージで糖質濃度の上昇が著しいことを考え合わ せると, 剣弁型の品種では花弁の向軸側表皮細胞において, 糖質濃度が著しく上昇することにより花形の差異を生じさ せている可能性がある.

\section{キンギョソウの花弁の展開にともなう 縁辺と花筒の糖質濃度の変動}

キンギョソウはバラとは異なり，その花弁は縁辺部分と 花筒部分とに明膫に区別することができる。このよらなタ イプの花はペチュニア，アサガオをはじめとして少なくな い. そこで，キンギョソウを用いて縁辺部分と花筒部分で それを構成する細胞の肥大と糖質の蓄積パターンが異なる のかを解析した。

キンギョソウ花筒の表皮細胞は直方体状であるのに対し て, 縁辺のそれは球状である. また, 花弁の展開にともな い花筒では肥大が緩慢であるのに対して，縁辺では特に最 終段階で急激に肥大寸る. 細胞が著しく肥大する縁辺では 糖質濃度は急増するが, 肥大が緩慢な花筒ではほぼ一定で ある. この結果は, 花弁の展開にともない, 細胞肥大程度 の違いにより糖質の上昇パターンが異なることを示してい る(乘越ら，2007）.

\section{今後の課題}

糖質の輸送と代謝にはさまざまな酵素タンパク質が関与 している。 また, 細胞が肥大するためには, 細胞に水が流 入するとともに細胞壁が緩むことが必要であると考えられ ている．細胞壁の緩みに関与しているタンパク質にはエク スパンシンなど，多くの酵素タンパク質がある. 花弁の展 開とこのよらな酵素タンパク質との関係についての研究が 最近推進されつつある（山田ら，2005; Yamada ら，2007）.

篩部からシンク細胞への輸送はアンローディングとその 後の輸送といら二つの段階からなるが，いずれの段階も原 形質連絡によるシンプラスト経由の経路とアポプラスト経 由の経路の 2 つ経路のどちらかが主体となっていると考 えられている. 花弁組織は主として向軸側表皮細胞, 背軸 側表皮細胞および柔細胞から構成されている. 輸送された 糖質はそれぞれの細胞に蓄積するが, 細胞の種類により蓄 積パターンが異なっている可能性がある.

糖質の蓄積と花弁細胞の肥大，ひいては花形との関係を
解明するためには，花弁を構成するそれぞれの細胞に打い て，篩部からのアンローディングとその後の輸送経路を明 らかにするとともに，糖質がそれぞれの細胞にどのよらに 蓄積するか明らかにすることが必要である.

謝 辞 本稿の作成にご協力いただいた名古屋大学生命 農学研究科の山田邦夫博士ならびに農研機構花き研究所の 乘越 亮博士に厚く御礼申し上げる.

\section{引用文献}

Bieleski, R. L. 1993. Fructan hydrolysis drives petal expansion in the ephemeral daylily flower. Plant Physiol. 103: 213-219.

Cosgrove, D. J. and R. E. Cleland. 1983. Solutes in the free space of growing stem tissues. Plant Physiol. 72: 326-331.

Cram, W. J. 1976. Negative feedback regulation of transport in cells. The maintenance of turgor, volume and nutrient supply. p. 284-316. In: U. Lüttga and M. G. Pitman (eds.). Encyclopedia of Plant Physiology. New Series Vol. 2. Transport in plants II. Part A. Cells. Springer-Verlag, Berlin.

Damon, S., J. Hewitt, M. Nieder and A. B. Bennett. 1988. Sink metabolism in tomato fruit. II. Phloem unloading and sugar uptake. Plant Physiol. 87: 731-736.

Enomoto, H., K. Kohata, M. Nakayama, Y. Yamaguchi and K. Ichimura. 2004. 2-C-methyl-D-erythritol is a major carbohydrate in petals of Phlox sublata possibly involved in flower development. J. Plant Physiol. 161: 977-980.

Evans, R. Y. and M. S. Reid. 1988. Changes in carbohydrates and osmotic potential during rhythmic expansion of rose petals. J. Amer. Soc. Hort. Sci. 113: 884-888.

Farré, E. M., A. Tiessen, U. Roessner, P. Geigenberger, R. N. Trethewey and L. Willmitzer. 2001. Analysis of the compartmentation of glycolytic intermediates, nucleotides, sugars, organic acids, amino acids, and sugar alcohols in potato tubers using a nonaqueous fractionation method. Plant Physiol. 127: 685-700.

Gerhardt, R. and H. W. Heldt. 1984. Measurement of subcellular metabolite levels in leaves by fractionation of freeze-stopped material in nonaqueous media. Plant Physiol. 75: 542-547.

Ichimura, K., M. Kishimoto, R. Norikoshi, Y. Kawabata and K. Yamada. 2005. Soluble carbohydrates and variation in vaselife of cut rose cultivars 'Delilah' and 'Sonia' flowers. J. Hort. Sci. Biotech. 80: 280-286.

Ichimura, K., K. Kohata and R. Goto. 2000a. Soluble carbohydrates in Delphinium and their influence on sepal abscission in cut flowers. Physiol. Plant. 108: 307-313.

Ichimura, K., K. Kohata, M. Koketsu, M. Shimamura and A. Ito. 1998. Identification of pinitol as a main sugar constituent and changes in its content during flower bud development in carnation (Dianthus caryophyllus L.). J. Plant Physiol. 152: 363-367. 
Ichimura, K., K. Kohata, M. Koketsu, Y. Yamaguchi, H. Yamaguchi and K. Suto. 1997. Identification of methyl $\beta$ glucopyranoside and xylose as soluble sugar constituents in roses (Rosa hybrida L.). Biosci. Biotechnol. Biochem. 61: 1734-1735.

市村一雄・木幡勝則・是永 勝・久松 完. 1997. トルコ ギキョウ切り花の品質保持に及ぼすスクロース処理の 影響ならびにその糖組成. 園学雑. 66 (別 2) : 614-615.

Ichimura, K., K. Kohata, Y. Mukasa, Y. Yamaguchi, R. Goto and K. Suto. 1999a. Identification of L-bornesitol and changes in its content during flower bud development in sweet pea (Lathyrus odoratus L.). Biosci. Biotechnol. Biochem. 63: 189-191.

Ichimura, K., K. Kohata, Y. Yamaguchi, M. Douzono, H. Ikeda and M. Koketsu. 2000b. Identification of L-inositol and scyllitol and their distribution in various organs in chrysanthemum. Biosci. Biotechnol. Biochem. 64: 865-868.

市村一雄・乘越 亮・清水弘子・木幡勝則. 2005. リンド ウの開花に打けるゲンチオビオースとゲンチオトリ オースの生理的役割. 園学雑. 74 (別 1) : 373 .

Ichimura, K., S. Ueyama and R. Goto. 1999b. Possible roles of soluble carbohydrate constituents in cut rose flowers. J. Japan. Soc. Hort. Sci. 68: 534-539.

Kenis, J. D., S. T. Silvente and V. S. Trippi. 1985. Nitrogen metabolism and senescence-associated changes during growth of carnation flowers (Dianthus caryophyllus). Physiol. Plant. 65: 455-459.

Koning, R. E. 1984. The roles of plant hormones in the growth of the corolla of Gaillardia grandiflora (Asteraceae) ray flowers. Amer. J. Bot. 71: 1-8.

Leigh, R. A. and A. D. Tomos 1993. Ion distribution in cereal leaves: Pathways and mechanisms. Phil. Trans. R Soc. Lond. B 341: 75-86.

MacDougall, A. J., R. Parker and R. R. Selvendran. 1995. Nonaqueous fractionation to assess the ionic composition of the apoplast during fruit ripening. Plant Physiol. 108: 16791689.

McKenzie, M. J., L. A. Greer, J. A. Heyes and P. L. Hurst. 2004. Sugar metabolism and compartmentation in asparagus and broccoli during controlled atmosphere storage. Postharv. Biol. Technol. 32: 45-56.

Moore, B. d., D. E. Palmquist and J. R. Seemann. 1997. Influence of plant growth at high $\mathrm{CO}_{2}$ concentrations on leaf content of ribulose-1,5-bisphosphate carboxylase/oxygenease and intracellular distribution of soluble carbohydrates in tobacco, snapdragon, and parsley. Plant Physiol. 115: 241-248.

乘越 亮・今西英雄・市村一雄. 2007. キンギョソウの花 冠展開にともなら浸透圧および糖質濃度の変動. 園学 研. 6 (別 2) : 333 .

乘越 亮・山田邦夫・鈴木克己・今西英雄・市村一雄. 2003.
バラ花弁に拈けるアポプラスト液の糖質含量の測定. 園学雑. 72 (別 2) : 465.

乘越 亮・山田邦夫・鈴木克己・今西英雄・市村一雄. 2005 . バラ花弁の展開時に打ける浸透圧の変化と糖質の役 割. 園学雑. 74 (別 2) : 501 .

Riens, B., G. Lohaus, D. Heineke and H. W. Heldt. 1991. Amino acid and sucrose content determined in the cytosolic, chloroplastic, and vacuolar compartments and in the phloem sap of spinach leaves. Plant Physiol. 97: 227-233.

Shimizu, H. and K. Ichimura. 2005. Effects of silver thiosulfate complex (STS), sucrose and their combination on the quality and vase life of cut Eustoma flowers. J. Japan. Soc. Hort. Sci. 74: 381-385.

Speer, M. and W. M. Kaiser. 1991. Ion relations of symplastic and apoplastic space in leaves from Spinacia oleracea L. and Pisum sativum L. under salinity. Plant Physiol. 97: 990-997.

Tsurusaki, K., Y. Matuda and N. Sakurai. 1997. Distribution of indole-3-acetic acid in the apoplast and symplast of squash (Cucurbita maxima) hypocotyls. Plant Cell Physiol. 38: 352-356.

Vergauwen, R., W. van den Ende and A. van Laere. 2000. The role of fructan in flowering of Campanula rapunculoides. J. Exp. Bot. 51: 1261-1266.

Wagner, G. J. 1979. Content and vacuole/extravacuole distribution of neutral sugars, free amino acids, and anthocyanin in protoplasts. Plant Physiol. 64: 88-93.

Welbaum, G. E. and F. C. Meinzer. 1990. Compartmentation of solutes and water in developing sugarcane stalk tissue. Plant Physiol. 93: 1147-1153.

Winter, H., D. G. Robinson and H. W. Heldt. 1993. Subcellular volumes and metabolite concentrations in barley leaves. Planta 191: 180-190.

Winter, H., D. G. Robinson and H. W. Heldt. 1994. Subcellular volumes and metabolite concentrations in spinach leaves. Planta 193: 530-535.

Yamada, K., M. Ito, T. Oyama, M. Nakada, M. Maesaka and S. Yamaki. 2007. Analysis of sucrose metabolism during petal growth of cut roses. Postharv. Biol. Technol. 43: 174-177.

山田邦夫・三島慶子・尾山智子・前坂昌宏・山木昭平. 2005. バラ花弁の生長に伴らエクスパンシン mRNAの発現解 析. 園学雑. 74 (別 1) : 442 .

Yamaki, S. 1984. Isolation of vacuoles from immature apple fruit flesh and compartmentation of sugars, organic acids, phenolic compounds and amino acids. Plant Cell Physiol. 25: $151-166$.

Yamaki, S. and M. Ino 1992. Alteration of cellular compartmentation and membrane permeability to sugars in immature and mature apple fruit. J. Amer. Soc. Hort. Sci. 117: 951-954.

Yoshida, K., T. Kondo, Y. Okazaki and K. Katou. 1995. Cause of blue petal colour. Nature 373: 291. 